George, P. \& Irvine, D. H. (1954). Biochem. J. 58, 188. Gibbs, W. M. (1919). Soil Sci. 8, 427.

Hofman, T. \& Lees, H. (1953). Biochem. J. 54, 579.

Lees, H. (1952). Biochem. J. 52, 134.

Lees, H. (1954). Autotrophic Microorganisms, p. 93. Cambridge University Press.

Lees, H. \& Quastel, J. H. (1945). Nature, Lond., 155, 276.

Lees, H. \& Quastel, J. H. (1946). Biochem. J. 40, 803.

Lees, H. \& Simpson, J. R. (1955a). Biochem. J. 59, i.

Lees, H. \& Simpson, J. R. (1955b). Biochem. J. 59, xvi.
Meyerhof, O. (1916a). Pfüg. Arch. ges. Physiol. 164, 353. Meyerhof, O. (1916b). Pflüg. Arch. ges. Physiol. 165, 229.

Partington, J. R. (1939). Textbook of Inorganic Chemistry, 5th ed. London: Macmillan and Co. Ltd.

Quastel, J. H. \& Scholefield, P. G. (1951). Bact. Rev. 15, 1. Simpson, J. R. (1955). Studies on the Biochemistry of the Nitrifying Bacteria. Thesis: University of Aberdeen.

Winogradsky, S. (1890). Ann. Inst. Pasteur, 4, 213, 257, 760.

Winogradsky, S. (1891). Ann. Inst. Pasteur, 5, 92, 577.

\title{
The Annelid Phosphokinases
}

\author{
By G. E. HOBSON AND K. R. REES \\ Marine Biological Association Laboratory, Plymouth, and the Department of Biochemistry, \\ University College, London
}

(Received 13 July 1956)

Roche and his co-workers (Thoai, Roche, Robin \& Thiem, 1953; Thoai \& Robin, 1954) have described the isolation of taurocyamine and glycocyamine from a number of annelid worms and this work has been confirmed by Ackermann $(1955 a, b)$. It was suggested that these bases when phosphorylated on the terminal amino group functioned as 'phosphagens'. Thoai et al. (1953) and Hobson \& Rees (1955) showed that these bases and creatine were present as the phosphates in annelid muscle. Further support for this concept is given by the evidence presented in this paper, that the annelids contain phosphokinases capable of phosphorylating taurocyamine, glycocyamine and creatine at the expense of adenosine triphosphate (ATP); the reactions can be expressed as a generalized version of the Lohmann reaction: guanidine base $+\mathrm{ATP} \rightleftharpoons$ phosphagen + ADP. A preliminary report of this work was presented by Hobson (1955).

\section{METHODS}

Extraction of enzymes. The animal was cooled in sea water until it was torpid; the gut was removed where this was practicable. To the weighed muscle of the body wall was added 2 vol. of ice-cold distilled water and the tissue was ground in a cold mortar with a little acid-washed sand. The extract was allowed to stand at $0^{\circ}$ for $10 \mathrm{~min}$. and then 5 vol. of cold acetone was added with stirring. The extract was filtered and the acetone-dried powder placed in a vacuum desiccator over anhydrous $\mathrm{CaCl}_{2}$. The powder proved stable for several months if stored at $2^{\circ}$.

For the transphosphorylation experiments $2 \mathrm{~g}$. of the acetone powder was ground with $10 \mathrm{ml}$. of distilled water and the extract dialysed against water for $15 \mathrm{hr}$. at $0^{\circ}$. The insoluble material was removed by centrifuging and the clear supernatant used for the experiments.

Transphosphorylation system. This was based on the system described by Lardy, Kuby \& Noda $(1954 a, b)$ for their studies on creatine phosphokinase. The final concentrations present were: guanidine base, 0.024 M; ATP, $0.005 \mathrm{M} ; \mathrm{MgSO}_{4}, 0.0003 \mathrm{M}$; glycine buffer, $0.1 \mathrm{~m}$ (pH 9.0); $0.4 \mathrm{ml}$. of enzyme soln. was added. The final vol. was $3 \mathrm{ml}$. and incubation was for $15 \mathrm{~min}$. at $40^{\circ}$. This system was found to give maximum phosphorylation, the addition of all components being necessary for phosphorylation of the base. The reaction was completed in about $10 \mathrm{~min}$. and there was no evidence of inactivation of the enzyme at this temperature nor of any breakdown of the phosphagens before analysis.

Materials. Creatine, taurocyamine and glycocyamine were commercial preparations (L. Light and Co. Ltd.). ATP was prepared by the method of Dounce, Rothstein, Beyer, Meier \& Freer (1948). Creatine phosphate was prepared by the method of Ennor \& Stocken (1948).

Determinations. The quantity of phosphagens was determined after transphosphorylation experiments as follows. The reaction was stopped by the addition of $2 \mathrm{ml}$. of ice-cold $20 \%$ (w/v) trichloroacetic acid to the incubation mixture. The mixture was cooled for $5 \mathrm{~min}$. in crushed ice and then centrifuged at $600 \mathrm{~g}$ for $5 \mathrm{~min}$. at $0^{\circ}$. The clear supernatant was neutralized (pink to phenolphthalein) and the $\mathrm{Ca}(\mathrm{OH})_{2}-\mathrm{CaCl}_{2}$ reagent of Fiske \& Subbarow (1929) was added to precipitate the inorganic and nucleotide phosphates. After standing for $10 \mathrm{~min}$. in ice the tubes were centrifuged. The phosphagens were estimated in the supernatants by the method described by Baldwin \& Yudkin (1950).

The solvents used in chromatographic analysis of the guanidine phosphates and guanidine bases were as described by Hobson \& Rees (1955). The chromatograms were run at $26.5^{\circ}$ and not, as reported earlier by us, at $22^{\circ}$.

\section{RESULTS}

Enzyme extracts were prepared from a number of errant and sedentary polychaete worms and portions $(0.4 \mathrm{ml}$.) were incubated in the standard medium with each of the four substrates, taurocyamine, glycocyamine, arginine and creatine. The

Bioch. 1957, 65 
results (Table 1) of a series of experiments show that one or other guanidine phosphate was formed in each case.

To characterize the product of the reaction, the phosphagens were separated and chromatographed. They were freed from the substrates after the addition of trichloroacetic acid and calcium reagent by precipitation at $0^{\circ}$ with 3 vol. of ice-cold acetone, and then dissolved in the minimum quantity of water. This procedure was repeated twice. The solutions were either chromatographed directly, phosphagens extracted directly from the muscle of the animal from which the enzyme had been prepared being used as markers, or alternatively phosphagens were hydrolysed with $\mathrm{N}-\mathrm{HCl}$ at $100^{\circ}$ for $5 \mathrm{~min}$. and the free bases chromatographed against markers of known identity. In all cases, as had been previously reported by Hobson \& Rees (1955), the $R_{F}$ value of the base liberated by hydrolysis of the phosphagens was the same as the $R_{F}$ value of the base which had been added to the incubation medium. The $R_{F}$ values of the synthesized and extracted phosphagens (Table 2) also agreed. For comparison the $R_{F}$ value of chemically synthesized creatine phosphate is included.

\section{DISCUSSION}

It is assumed that where a base is phosphorylated to any appreciable extent this can be taken as evidence for the view that the compound produced would act as a phosphagen in vivo fulfilling the same functions as the well-known phosphagens, arginine and creatine phosphates, in muscular activity. Although the enzyme extracts from the different species were not found to be specific for a single base, the work described here supported the earlier evidence for the existence of new phosphagens (Thoai et al. 1953;

Table 1. Enzymic synthesis of the guanidine phosphates

Medium for transphosphorylation as described in the Methods section.

$\begin{array}{ccccc}\text { Source of enzyme preparation } & \begin{array}{c}\text { Taurocyamine } \\ \text { phosphate }\end{array} & \begin{array}{c}\text { Glycocyamine } \\ \text { phosphate }\end{array} & \begin{array}{c}\text { Arginine } \\ \text { phosphate }\end{array} & \begin{array}{c}\text { Creatine } \\ \text { phosphate }\end{array} \\ \text { Arenicola marina (body wall) } & \mathbf{5 \cdot 0} & 1 \cdot 25 & 0 & 0 \\ \text { Nereis diversicolor } & \mathbf{0 . 4} & \mathbf{6 . 5} & 0 & 0 \\ \text { N. fucata } & 0 & 5.8 & 0 & 2 \cdot 0 \\ \text { Hermione hystrix } & 0 & 0 & 0 & \mathbf{4 . 5} \\ \text { Aphrodite aculeata } & 0 & 0 & 0 & 1.25 \\ \text { Myxicola infundibulum } & 1.5 & 0 & 0 & 0 \\ \text { Nephthys cacea } & 0 & 1 \cdot 7 & 0 & \mathbf{1 . 7}\end{array}$

Table 2. Chromatographic analysis of the guanidine phosphates

Method of preparation or isolation of the phosphagens is described in the text. TP, GP and CP represent taurocyamine, glycocyamine and creatine phosphate respectively.

\begin{tabular}{|c|c|c|c|}
\hline \multirow{3}{*}{ Source of phosphagen } & & \multicolumn{2}{|c|}{ Solvent systems } \\
\hline & \multirow{2}{*}{$\begin{array}{l}\text { Nature of } \\
\text { phosphagen }\end{array}$} & $\begin{array}{c}\text { Propan-1-ol- } \\
\left.\mathrm{NH}_{\mathrm{s}} \text { soln. (sp.gr. } 0 \cdot 88\right)- \\
\text { water }(6: 3: 1 \text {, by vol.) }\end{array}$ & $\begin{array}{c}\text { isoPentanol- } \\
\text { pyridine- } \\
\text { water }(4: 8: 7, \text { by vol. })\end{array}$ \\
\hline & & $R_{F}$ & values \\
\hline Arenicola marina body wall & TP & 0.24 & $0 \cdot 19$ \\
\hline $\begin{array}{l}\text { Synthesized with } A . \text { marina } \\
\text { enzyme }\end{array}$ & TP & 0.23 & $0 \cdot 18$ \\
\hline Nereis diversicolor & GP & 0.20 & 0.08 \\
\hline $\begin{array}{l}\text { Synthesized with } N \text {. diversicolor } \\
\text { enzyme }\end{array}$ & GP & $0 \cdot 19$ & $0 \cdot 09$ \\
\hline Glycera gigantea body wall & $\begin{array}{l}\text { TP } \\
\text { CP }\end{array}$ & $\begin{array}{l}0 \cdot 24 \\
0 \cdot 29\end{array}$ & 二 \\
\hline $\begin{array}{l}\text { Synthesized with } G \text {. gigantea } \\
\text { enzyme }\end{array}$ & $\begin{array}{l}\text { TP } \\
\text { CP }\end{array}$ & $\begin{array}{l}0 \cdot 24 \\
0 \cdot 29\end{array}$ & 二 \\
\hline Hermione hystrix & CP & 0.30 & - \\
\hline $\begin{array}{l}\text { Synthesized with } H \text {. hystrix } \\
\text { enzyme }\end{array}$ & CP & 0.31 & - \\
\hline Chemically synthesized & CP & 0.30 & - \\
\hline
\end{tabular}


Hobson \& Rees, 1955) and served to identify them by synthetic as opposed to degradative means. Throughout the species investigated the phosphokinases predicted by the previous results were all proved to be present and capable of phosphorylating the expected base.

As was reported for some of the echinoderms (Needham \& Baldwin, 1937), several annelids, e.g. Glycera gigantea, Nereis diversicolor and Myxicola infundibulum, contain a mixture of phosphagens and show that the enzyme systems for the synthesis and utilization of phosphagens in living muscle are completely duplicated.

The experimental results again emphasize that creatine phosphate, acting as a phosphagen, is not confined to the echinoderms, protochordates and vertebrates, but is also present, often in considerable quantities, in the annelids. At the present time the distribution of creatine phosphate appears quite arbitrary. This fact lessens the value of the identification of the phosphagens in evolutionary studies in the animal kingdom.

\section{SUMMARY}

1. A method of extraction of guanidine phosphokinases from annelid muscle is described.

2. Transphosphorylation has been demonstrated and the synthesized guanidine phosphates have been identified.
3. It is concluded that taurocyamine and glycocyamine phosphate as well as creatine phosphate can act as phosphagens in certain of the annelids.

We would like to express our appreciation to the staff of the Marine Biological Laboratory, Plymouth, who provided much living material, and to the administrators of the Field Fund of University College, London, for a grant to cover part of this work. Also our thanks are due to Professor E. Baldwin for his advice and encouragement in this work.

\section{REFERENCES}

Ackermann, D. (1955a). Hoppe-Seyl. Z. 299, 186.

Ackermann, D. (1955b). Hoppe-Seyl. Z. 302, 80.

Baldwin, E. \& Yudkin, W. H. (1950). Proc. Roy. Soc. B, 136, 614.

Dounce, A. L., Rothstein, A., Beyer, G., Meier, R. \& Freer, R. M. (1948). J. biol. Chem. 174, 261.

Ennor, A. H. \& Stocken, L. A. (1948). Biochem. J. 43, 190. Fiske, C. P. \& Subbarow, Y. (1929). J. biol. Chem. 81, 629.

Hobson, G. E. (1955). Biochem. J. 60, viii.

Hobson, G. E. \& Rees, K. R. (1955). Biochem. J. 61, 549.

Lardy, H. A., Kuby, S. A. \& Noda, L. (1954a). J. biol. Chem. $209,191$.

Lardy, H. A., Kuby, S. A. \& Noda, L. (1954b). J. biol. Chem. 210, 65.

Needham, D. M. \& Baldwin, F. (1937). Proc. Roy. Soc. B, $122,197$.

Thoai, N.-V. \& Robin, Y. (1954). Biochim. biophys. Acta, 13, 533.

Thoai, N.-V., Roohe, J., Robin, Y. \& Thiem, N.-V. (1953). C.R. Soc. Biol., Paris, 147, 1241.

\title{
Protein Synthesis in Guinea-pig Liver \\ INCORPORATION OF RADIOACTIVE AMINO ACIDS INTO PROTEINS OF THE MICROSOME FRACTION IN VIVO
}

\author{
By J. L. SIMKIN AND T. S. WORK \\ National Institute for Medical Research, The Ridgeway, London, N.W. 7
}

(Received 11 July 1956)

When a labelled amino acid is injected intravenously into normal animals the liver protein becomes rapidly labelled. Fractionation of the liver subcellular components by differential centrifuging has shown that there is a high rate of incorporation of amino acid into the proteins of the microsome fraction (Borsook, Deasy, Haagen-Smit, Keighley \& Lowy, 1950; Hultin, 1950; Keller, 1951). It has been shown, also, that most of the cytoplasmic ribonucleic acid is concentrated in the microsome fraction and that, at least with pancreas, digestion of the microsomes by ribonuclease releases a protein with a particularly high turnover rate (Allfrey, Daly \& Mirsky, 1953).
The present investigation was designed to gain additional information concerning the role of the microsome fraction in protein synthesis. It was found, following a suggestion by Dallam (1955), that further fractionation of the microsome material of guinea-pig liver could be achieved by extraction with solutions of varying ionic strength and $\mathrm{pH}$. This method was used to follow the rate of incorporation of radioactive amino acids into different microsome proteins after injection of a mixture of $\left[{ }^{14} \mathrm{C}\right]$ amino acids into normal guinea pigs. Our results indicate that the microsome fraction contains a complex mixture of proteins with widely differing turnover rates, the protein fraction with the highest turnover 